\title{
教育講演健保適用漢方製剂とその運用法
}

\author{
Application of Ethical Kampo Drugs
}

菊谷 豊彦

\section{Toyohiko KIKUTANI}

本日は，医療用漢方製剂の運用法についてお話 しをしたいと思います。

\section{2 剤併用とその問題点}

2 剂併用，これは名前の問題で合方といってみ たり，あるいは複方といらような言葉があるかと 思いますが，私自身も2 率併用といったり 2 剂合 方といってみたり, 自分自身の心も摇れているよ らな気もします。このような問題に関しては, 必 ずしもこの学会でも内部で一致をみていない問題 であろらと思います。1剤で十分ではないかとい ら考劣ももちろんございますし，しかし臨床上ど らしても必要だといら考えもごさいます。今回の 演題をみていても, 中川先生は複方の必要性を強 調して扣られますし, また午後から行われる講演 でも, 山田先生が関節炎関係の疾患に, いろいろ な合方，併用を行って扔られます。そういったと ころで, 保険医療上の必要性から考兄て, 私自身 は，合方は非常に重要な問題と考劣ています。

合方というのは, 本来エキス剤ではなく, 煎薬 について用いられる用語で, 合方例としては『傷 寒論』『金實要略』でも桂麻各半湯, 桂枝二越婢 一湯, 桂姜霖草黄辛附湯などは, 本来は合方です がすすで独立した処方として存在するといらよ らに考光られて和ります。また，合方としてもし
ばしば用いられておりますのは, 柴朴湯, 柴苓湯 などでこれも一つの独立処方であります。ま た, 古方と後世方とが合方されたものとしては, 四物湯と苓桂术甘湯の聯珠飲, 平胃散と五苓散が 合方された胃苓湯，あるいは小柴胡湯と四物湯の 合方などもございます。また, 後世方と後世方と が合方されたものとしては, 四物湯合四君子湯が 八珍湯, 黄連解毒湯と四物湯が温清飲となってい ます。こういったことは, 皆様ご承知のことと思 います。

後世方の中にいくつかの処方の合方によって成 立したものとあります。たと竞ば, 柴葛解肌湯は 葛根湯と小柴胡湯と白虎湯の証を合わせて, 三陽 の合病の証に対応するものであります。また慢性 病でいろいろな病気が重複してきますと, このよ らな複雑な病態が表れ, 合方の必要性が生じてく ると考えられます。

江戸時代の古方家, 吉益南涯, 宇津木昆台, 尾 台榕堂らは, しばしば合方や兼用を用い，また昭 和初期には古方家の湯本求真, 後世派の森道伯 が，その晚年に盛んに合方を用いたのも有名な事 実であります。湯本求真の合方は, 腹診上胸脇苦 満があれば大柴胡湯あるいは小柴胡湯, 臍傍の抵 抗圧痛があれば桂枝获苓丸, 大黄丹皮牡湯, 小腹 急結があれば桃核承気湯など， $2 \sim 4$ 方を合方し

医, 日本東洋医学会常務理事

M. D., Standing Director of the Japan Society for Oriental Medicine 
表 1 二剂合方

\begin{tabular}{|c|c|c|}
\hline 煎 & 郕 & 漢方製羭 \\
\hline 煎 & 液 & 混合 \\
\hline $\begin{array}{l}\text { 共通生薬の } \\
\text { 少ない生薬; }\end{array}$ & $\begin{array}{l}\text { ちち, 量の } \\
\text { 除かれる。 }\end{array}$ & $\begin{array}{l}\text { 満量使用では共通生薬 } \\
\text { が過量となる。 }\end{array}$ \\
\hline
\end{tabular}

表 2 漢方診療に括将る処方の用い方

\begin{tabular}{c|c}
\hline \multicolumn{1}{c|}{ 煎 剂 } & 製 剤 \\
\hline 単方 $(147$ 処方 $)$ & 単 方 \\
\hline 単方 $(147$ 処方以外 $)$ & 合 方 \\
\hline 加 方 & 合 方 \\
\hline 去 方 & 不可能 \\
\hline 合 方 & 合 方 \\
\hline
\end{tabular}

たといらことも知られております。

また，合方に対する注意としては，『腹証奇覧』 の著者稲葉文礼が，「みだりに合方加減して方法 を改易してはならない。効かないばかりでなく， 害になることが多い。初学者はとくにこの点に注 意しないと, 単方の上達は望めない」ともいって おります。

そういった意味で，合方に関しては非常に難し い問題がありますが，私はあえて保険診療の立場 から，先生方にご説明申し上げたいと思います。

\section{漢方診療における合方の考え方}

漢方診療では湯液の単方，あるいは去加方，さ らに 2 剂合方あるいは兼用といらものがあります (表 1 )。

それに対して槊剂の場合は，共通生薬のうち量 の少ない生薬を除くといらことであります。漢方 製剂の場合は，2剂合方は満量使用では共通生薬 が過量となることは問題点ではありますが，量の 加減をある程度やれば，かなり煎薬に近いものが 得られることも事実だと思います。しかし，薬学 的な面あるいは薬理学的な面で, 問題が残ること は当然のことだと思います。

現在, 漢方の保険訬療を行ら場合に, 製剤の場 合は単方として147処方があります。しかし，147 処方以外のものを作万らとすれば，合方するある
表 3 近年の疾病の多様化, 複雑化
(1) 心身症
(2) 膠原病
（3）ステロイド剤内服
（4）老人性疾患
（5）ウイルス性疾患

表 4 二剂合方の目的と必要性
（1）全身症状の重視と治癒の促進
(2) 治療領域の拡大と深化
(3) 複数の病態の存在
(4) 新しい病態の「証」への対応
(5) 副作用の緩和
(6) 古典の処方に合せる目的
(7) 先人の合方・加方に合せる目的

いは単味の生薬末を加えることしかないわけであ ります。加方を行拈らと思っても，実際には合方 しなければならないといらこともしばしばござい ます。また去加方のらち，去方の場合は不可能で あります。煎剤として合方の場合には，製剂とし て合方が可能な場合も多くあろらかと思います (表 2 )。

名称は合方といったり併用といってみたり，あ るいは中川先生のような複方といら表現もあろう かと思います。本来煎薬に対して用いられた合方 といら言葉を，この席でェキス剂に対しても，合 方という言葉を使わせて頂くよう拈許し願いたい と思います。あるいは，併用といら言葉も，けっ して捨てられるような問題でもないと思いますの で，こういういい方を私自身がするかもわかりま せん。これも扐許し願いたいと思います。

保険診療上の要望事項はたくさんあると思いま すが，単味生薬のエキス製剤の薬価收載につい て，私は大変望んでいるところであります。立 た，新規漢方製剤の承認と薬価収載，これは医療 用が147処方，一般用は 210 処方といわれておりま す。ふつうですと, 医療用が 147 処方であれば, 一般用はそのらち本当に一般用として妥当なもの を，たとえば半分とか 3 分の 1 といら具合に使わ れるのですが，いままでの経過から申しまして， 一般用がたくさんあるにもかかわらず，医療用は 
(121)

表 5 生薬単味製剤による処方の代用

\begin{tabular}{|c|c|c|c|c|c|c|c|}
\hline \multicolumn{2}{|c|}{ 生薬単味製 剂 } & 漢 & 方 & 垁 & y & 剤 & \\
\hline 甘 & 草 & 甘 & & 草 & & & 湯 \\
\hline 桔 & 梗 & 桔 & & 梗 & & & 湯 \\
\hline 大 & 黄 & 大 & 黄 & 甘 & 草 & & 湯 \\
\hline 莐 & 薬 & 苻 & 薬 & 甘 & 草 & & 湯 \\
\hline 人 & 参 & 人 & & 参 & & & 湯 \\
\hline 石 & 膏 & 枯 & 梗 & & 石 & & 膏 \\
\hline 半 & 夏 & 小半 & 乍夏 & 加 & 获 & & 湯 \\
\hline
\end{tabular}

表 6 合方による処方の作用

\begin{tabular}{|c|c|c|}
\hline 処 方 名 & の 方 & 法 \\
\hline 甘草瀉心湯 & $\begin{array}{l}\text { 半夏瀉心湯エキ友顆粒(散) } \\
\text { 甘草激粒(散) }\end{array}$ & $\begin{array}{l}5 \mathrm{~g} \\
5 \mathrm{~g}\end{array}$ \\
\hline 葛根湯加桔梗 & $\begin{array}{l}\text { 葛根湯エキス顆粒(散) } \\
\text { 梗エキス顆粒(散) }\end{array}$ & $5 \mathrm{~g}$ \\
\hline $\begin{array}{l}\text { 大柴胡湯の大黄 } \\
\text { 增量 }\end{array}$ & $\begin{array}{l}\text { 大柴胡湯エキス顆粒(散) } \\
\text { 大黄湯エキ顆粒(散) }\end{array}$ & $5 \mathrm{~g}$ \\
\hline 柴胡桂枝湯加苻 & $\begin{array}{l}\text { 柴胡棈枝湯エキス顆粒(散) } \\
\text { 芳楽甘キス顆粒(散) }\end{array}$ & $\begin{array}{l}5 \mathrm{~g} \\
5 \mathrm{~g}\end{array}$ \\
\hline 葛根加半夏湯 & $\begin{array}{l}\text { 慕根湯エキス顆粒(散) } \\
\text { 顆粒(加获荅湯エキス } \\
\end{array}$ & $\begin{array}{l}5 \mathrm{~g} \\
5 \mathrm{~g}\end{array}$ \\
\hline
\end{tabular}

147 とらように限定されているということで， 注かの医薬品とは異なった様相を呈しており, 現 在の薬務局の審査課では，147 処方以外に新しい 漢方製剤の承認に対しては, 生物学的同等性を求 めるといらことで，すでに10年以上その承認が見 送られているようであります。

最近の疾病構造の変化はいろいろあると思いま すが，その中でも慢性疾患の増加が大変多いと思 います（表 3)。たとえば心身症，膠原病などは 大変増加して扣ります。あるいは，ステロイド剂 の内服。ステロイド剂の内服を行らと, moon face やステロイド性瘀血の出現，あるいは上熱下冷と いったように，いろんな証の変動が起こってきま す。あるいは，老人性疾患があります。これも日 本がかつて経験したことがないよらな老人の増加 と共に， $5 \sim 6$ 疾患，あるいは人によっては10疾 患以上持つ老人性疾患の漢方治療というのは，日 本がはじめて経験するものではないかと思いま す。あるいは，種々のウイルス性疾患などに対応
日本東洋医学雑誌 第 41 巻第 3 号 (1991) 7

表 7 合方に上る保険適用外の処方の代用

\begin{tabular}{|c|c|}
\hline 保険適用外の処方 & 方 \\
\hline 蘇 & 小柴胡湯合香蘇散 \\
\hline 中 建 中 & $\begin{aligned} \text { 大建中湯合小建中湯 } & \text { (桂枝加苻薬湯 }\end{aligned}$ \\
\hline 珍 & 四物湯合四君子湯 \\
\hline 連珠 领 & \\
\hline 加味逍遥散加川涝地黄 & \\
\hline 小青竜湯加 获苓杏仁 & 小青 \\
\hline 桂姜呆草黄辛附湯 & 麻黄陌 \\
\hline 桂枝二越婢一湯加尤附 & 桂枝加 \\
\hline 五虎二陳湯 & 五虎 \\
\hline 大青 竜 湯 & 麻杏甘不 \\
\hline 小青竜湯加杏仁石膏 & 甘石湯 \\
\hline 柴苻六君子湯 & 四逆肖 \\
\hline 人参湯合真武湯 & \\
\hline 柴 葛 解 肌 湯 & 小柴胡湯合葛根湯加枮梗石膏 \\
\hline
\end{tabular}

していくには, 1 㓮だけでももちろん結 構です が，対応できない場合には，2剂， 3 剂の併用と いらことも考えるべきではないかと，私は思いま す。

\section{2 剂合方の目的と必要性}

2 剂合方の目的と必要性は, 表 4 亿示すように 全身症状の重視と治癒の促進といらことですが, もともと漢方は全身症状を重視しているではない かといら議論はもちろんありますが, やはり局所 を重視したような処方もありますし, 全身を重視 した処方もあります。そらしたときに全身症状の 重視といらことも当然人ってくるわけで, それと 治癒の促進といらことの絡みも, 私は重要ではな いかと思っております。それから，合方すると治 療領域が桩大して深まってきます。そらいったこ ともあろらかと思います。また，これは藤平先生 がしばしばいわれることですが, 併病の存在, 複 数の病態の存在の場合にも, 合方といらことが必 要だと思います。それから, 新しい種々の病態が 出てきたので，そらいった証への対応。これはい ままで日本で経験したことのないような，新しい 病態の証への対応といってもよいかと思います。 それから，副作用の緩和。これは本来あるべき ことではないかも知れませんが，多くの地黄凨は 
副作用の緩和をしてはじめて飲めるという，もっ ともこれは考㝋ようによっては，それなりの別の 証があるのではないかといらこともいえるかと思 います。あるいは古典の処方に合わせる目的。た と壳ば聯珠飲あるいは八珍湯などの処方は，保険 製剂にありませんので，聯珠飲を用いる場合には 四物湯と苓桂术甘湯の合方といらことが必要であ ります。それから，先人の合方，加方に合わせる 目的など，いろいろな目的で用いられるので，そ の合方された処方が，いったいどの目的に使わっ たかといらのは難しい問題で，明細書やュメント をみて判断できる問題であります。診療している 諸先生に执いては，二つ，三つの目的で报使いに なっている場合もあろらと思いますし，その内容 は非常に複雑だろらと思います。

\section{合方の実際}

実際には生薬単味製剂のないのが現実ですか ら，たとえば桔梗湯を桔梗の代わりに使う。葛根 湯加桔梗といら場合には，葛根湯に桔梗湯を加兄 るといら用い方があるわけです(表 5)。そらいら 意味で，桔梗湯を桔梗単味製剤の代用とするとい らわけであります。大黄甘草湯でも同じでありま す。これを大黄の代わりとして用いる。䓎薬甘草 湯を苻薬の代わりとして用いる。あるいは，小半 夏加获苓湯を半夏の代わりとして用いる。これは 少し間違っているといらご批判もあろうかと思い ますが，こらいった意味で合方するしかない場合 もあるわけです。

その一つの例ですが，甘草瀉心湯を作るには， 半夏瀉心湯に甘草湯を加える。大柴胡湯の大黄を 増量する場合には，大柴胡湯に大黄甘草湯を適量 加觉る。柴胡桂枝湯加苻薬を作るには，柴胡桂枝 湯に苟薬甘草湯を加える。このようないろいろな 合方の方法があるかと思います。これは単味エキ ス製剂があれば解決する問題ですが，現在では二 つの製剤を合わせることによって得られるものだ と思います（表 6)。

保険適応外の処方，とくに古典の処方ですが， あるいは先人の用いた処方もありますが，柴蘇飲 を用いる場合には，小柴胡湯と香蘇散の合方，中
建中湯を得る場合には, 大建中湯と小建中湯, あ るいは桂枝加䓎薬湯の合方が必要であります（表 7 ）。八珍湯は四物湯之四君子湯, 聯珠飲は四物 湯と苓桂术甘湯, 加味逍遥散加川芦地黄は加味逍 遥散に四物湯, 小青竜湯加获苓杏仁は小青竜湯に 苓甘姜味辛夏仁湯の合方, 桂姜菓草黄辛附湯を作 るには麻黄附子細辛湯と桂枝湯との合方，この場 合は桂枝湯の药薬がからんできますが，夰薬があ るといらのは本来ないことですが，これはやむを 得ないと思います。このようにいろいろな合方の 形態があるわけです。

実際に慢性肝炎を小柴胡湯単味で使った場合, どうしても効かない，裏に瘀熱のあるよらな場合 には, 茵蔯蒿湯の合方が必要でありますし, 同じ ように裏に疾熱があって，水毒がさらにからんで いるような場合には茵蔯五苓散, あるいは疼血が あるような場合には桂枝获苓丸, 血虚の症状があ るといら場合には四物湯，あるいは上衝があると いうょうな場合には黄連解毒湯，このような種々 の合方が必要になるわけであります。

喘息に扮いても, 小柴胡湯合半夏厚朴湯, 柴朴 湯が基本処方であると思いますが，小柴胡湯は一 つの本治法としての有効性を持っておりますし， 五虎湯, 麻杏甘石湯は標治法としての一つの症候 を除いていくような，たとえば喘鳴，呼吸困難な ぞに対応するには五虎湯, 小青竜湯, それと本治 法としての小柴胡湯との合方が必要な場合も多い と思います。虚証例であれば柴胡桂枝乾姜湯に麻 黄附子細辛湯, あるいは苓甘姜味辛夏仁湯との合 方なども必要だろうと思います。このように, 治 療効果の拡大深化を目指すことも，私は必要だろ らと思います。もちろん, 五虎湯, 麻杏甘石湯を 長期連用することも悪いとは申しませんが，虚弱 体質, 感冒, いろいろな呼吸器疾患などの喘息悪 化因子を除くには，やはり小柴胡湯をはじめとす るいろいろな漢方製剤を用いるべきだと，私は考 觉て扣ります。

例をアトピー性皮膚炎にとれば，現在のアトピ 一性皮膚炎では，ステロイド剤依存性となって非 常に難治となった例では, 漢方製剂一味を使った だけでは，顕著な改善は望めないと私は考光てお 
表 8 新しい病態に対応する合方

防已黄者湯合十全大補湯

変形性脊椎症, 変形性関節症, 骨粗鬆症, 浮腫,

腎疾患，虚労などを伴うもの。

老人性疾患に適する

八味地黄丸合補中益気湯

変形性资椎症, 骨粗鬆症, 夜間頻尿, 前立腺肥大,

虚労などを伴うもの。

老人性疾患に適する

表 9 漢方保険診療ハンドブック（昭和62年）

厚生省保険局医療課の委訳研究

(1) 漢方製剤の 2 剂合方

(2) 漢方薬と洋薬の侀用

(社)日本東洋医学会編

ります。たとえば，温清飲に非常に山渴があると きは白虎加人参湯，湿熱のある場合は越婢加术湯 の併用，消風散と柴胡清肝湯の位用といったよう な，種々の合厅を試みることが必然性を持って行 わなければならないと考光て拈ります。

高血生に沶いても同様で，黄連解毒湯と柴胡加 竜骨牡蚛湯の合方，あるいは加味逍遥散と七物降 下湯の合方，あるいは大柴胡湯と桂枝茯苓丸との 合方，これは当然柴胡加竜骨牡蚛湯だけでも構い ませんが，さらに上衝があって非常にのぼせが強 いときには，黄連解毒湯を僧用してよい場合が， 私は少なからずあると思います。そうした場合に は, 量への配慮, 満量を使らのではなくて, $5 \mathrm{~g}$ と $5 \mathrm{~g}$ だとか，あるいは片方を7.5 $\mathrm{g}$ にして片方を $5 \mathrm{~g}$ ぐらいにするとか，こらいった量への配慮も 当然必要だろらと思います。

感冒や咽喉頭炎の場合には，葛根湯と桔梗湯と の合方，あるいは小柴胡湯加桔梗石膏に麦門冬湯 との合方，桂枝湯と麻黄附子細辛湯との合方な ぞ，いろいろな合方の例があろらと思います。も ちろん 1 剤で用いることも大変よいと思います し, 必要性に応じて何らかの合方も, 漢方診療の 上で非常に重要だろらと考えております。

鼻アレルギーですが，今回，鼻アレルギーは燥 や熱が関与するといら中川先生の発表を頂きまし たが，私も常々考えて扣りまして，越婢加术湯の
よらな熱を除くような薬，あるいは麦門冬湯のよ らな薬も必要之考えております。さらに花粉症の 異常に長く継続するよらな例, 花粉症とともに咽 喉頭症状を伴うょうな例に抢いては小柴胡湯との 併用など，あるいは加味逍遥散との併用なども必 要だと考えて扮ります。そういうことによって， 長年の花粉症が寛解した例も，自分自身経験して おります。小柴胡湯と麻黄附子細辛湯の併用も, ときには必要だろらと思います。

老人性疾患が非常に増えて沶り，そらした中で 防已黄耆湯と十全大補湯，これは何ごとかと扮叱 りを受けることもあるだろらかと思いますが，こ のような病態が実際存在するようなことがまれで はないと思います（表８）。扮年寄りの疾患で骨粗 惖症がある，全身倦忠感がある，胃疾患がある， 腎疾患があるという場合には，このような病態が 存在することもあろらと思って扣ります。あるい は八味地黄丸と補中益気湯，八味地黄丸のような 腎虚に対する処方と，補中益気湯のような脾虚に 対するよらな処方との合方，これも変形性脊椎症 や骨粗鬆症，あるいは腎疾患，夜間頻尿，前立腺 肥大，疲労などを伴うものといらような，非常に 多くの老人性疾患ではこのようになりますし，そ の場合にはこのような合方も必要な場合もあると 考えて扣ります。

\section{諸先生の合方例}

実は，私はこの発表をする前に大変考えて，昭 和62年に厚生省保険局医療課から本学会に委託研 究がありまして，漢方製剂 2 剂合方と漢方薬と洋 薬の併用を中心として，その研究内容を提出せよ との命令がございました。これは実際には発行さ れておりませんで，現在では幻の本になって扣り ますが，それをひもといてみました。これは本学 会に所属しておられる高名な諸先生の，いろいろ な文献がひとまとめになったもので，私は大変有 用なものだと考光て拈ります（表 9)。

山田先生は合方例として，人参湯合真武湯を下 痢，食欲不振の強い虚証に用いる。あるいは，人 参湯合安中散は胃痛, 胸やけと食欲不振を兼衫る 虚証，胃潰瘍，胃炎に用いる。人参湯合猪苓湯は 
表10 合方剂（山田光胤）

（1）人参湯合真武湯

下痢, 食欲不振の強い虚証

（2）人参湯合安中散

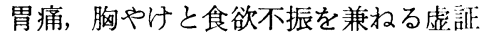

胃潰瘍. 胃炎

（3）人参湯合猪苓湯

胃腸虚弱者が泌尿器症状を呈するもの

(4) 香蘇散合小柴胡湯

急性耳管炎などによる耳鳴

（5）香蘇散合加味䝵遥散

加味逍遥証の神経症で, 気らつの強い虚㹬

(6) 香蘇散合六君子湯

香砂六君子湯の方意

六君子湯証で気分抑うつの場合

胃腸虚弱者の泌尿器症状を呈する者に用いるとい らようにいわれております。私自身も 1 と 2 のよ らな合方は，しばしば行っております。しかし， 人参湯合猪苓湯というのは, 私は五淋散や清心蓮 子飲を考劣ており，実はこれらは考えておりませ んで，大変よい勉強をさせて頂きました。

さらに先生は香蘇散と小柴胡湯, これは柴蘇飲 にあたるわけで，急性耳下腺炎，耳鳴りなどに。 香蘇散と加味逍遥散との合方, 加味逍遥散証で神

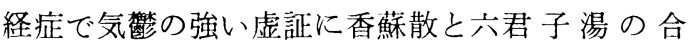
方，これは香砂六君子湯の方意で，六君子湯証で 気分抑鬱の場合，このような例を先生はあげてお られます（表10）。

さらに原敬二郎先生は, 安中散と二陳湯に加工 附子を加えて，枳縮二陳湯を作るといら，非常に 素晴らしい合方を示して扮られます(表11)。ある いは小柴胡湯に温清飲を，慢性皮膚疾患に用いる といらようなこともいって抢られます。麦門冬湯 と白虎加人参湯を竹葉石膏湯の方意として, 肺 炎，気管支炎などに用いるといらこともあげてお られます。

さらに小柴胡湯と竜胆瀉肝湯を慢性肝炎, 胆嚷 炎に用いる。小柴胡湯と防已黄者湯を慢性腎炎に 用いる。酸慗仁湯と防已黄者湯を慢性腎炎に用い る。酸柬仁湯と当帰药薬敢を合方で, 貧血, 冷兄 症で記憶力減退, 老人, 婦人の不眠, 昼夜逆転に 用いる。たしかに『類聚方』をみてみますと，文
表11 合方例（原敬二郎）

（1）安中散合二陳湯加加工附子 枳縮二陳湯の方意 肋間神経痛，狭心症など

（2）小柴胡湯合温清领 慢性皮膚疾患

（3）麦門冬湯合白虎加人参湯 竹葉石高湯の方意 肺炎, 気管支炎など

（4）小柴胡湯合竜胆瀉肝湯 慢性肝炎, 胆慗炎

（5）小柴胡湯合防已黄者湯 慢性腎炎

（6）酸霜仁湯合当州芺薬散 貧血，冷兄症で記憶力減退 老人，婦人の不胙，昼夜逆転： （類聚方広義）

章はやや違いますが，これと同じことが書いてあ りました。先生の博識に大变驚いた次第でありま す。このような合方があるということでありま す。㬰際に私も小柴胡湯と竜胆瀉肝湯を，あるい は小柴胡湯と防已黄耆湯などは，合方として使っ て扣りますが，このような酸霖仁湯と当帰莎薬散 の合方例は私自身は使った例はございません。

漢方製剂の用量は，老人であれば 3 分の $2 ， 2$ 分の 1 に減量してみたり，あるいは 2 剂併用のと き，作用効果に其通面がある場合には 3 分の 2 量 にしてみたり，あるいは満量と 3 分の 2 量に減量 してみたり，あるいは半量と半量にしてみたり， いろんな方法があろらと思いますが，量の面で の，とくに作用効果に共通面がある場合には減量 をする必要があろらかと思います。

合方上の問題点と致しましては, 甘草, 大黄, 地黄，附子，石高などの過量にやはり気を付ける べきだと思います(表12)。したがって構成生薬を 十分知ることが大事だと思います。それから，も ちろん方剂の構成生薬を知らないままに合方する 危険性，これと同じょうな意味ですが，大変危険 だと思います。方剤の使用法を熟知しないまま， 2 凨を合方するといらことは，漢方医学を歪める といら点ももちろんあると思います。

代田先生は，表13のよらにいっておられます。 
表12 合方上の問題点

（1）甘草, 大黄, 地黄, 附子, 石膏なぞの過量

(2) 方鼡の構成生薬を知らないまま合方する危険

（3）方珮の使用法を熟知しないまま，2剤合方する ことは, 漢方医学を歪める。

表13避けることが望ましい合方例（代田文彦）

1. 既に合方されている方剤があるため, 構成処方 が重複する。

(1) 温清飲合黄連解䏝湯

(2) 柴苓湯合五苓散

2. 同じ系統に属するもの, 同じ作用をめざす方剂 の合方

（1）大柴胡湯合柴胡桂枝乾姜湯

（2）八味地黄丸合六味丸

（3）桂枝获苓丸合桃核承気湯

3.証があまり以もか汁離机ているものの組合せ

(1) 桃核承気湯合真武湯

4. 含有生薬の重複により副作:用が蜼現する可能性

(1) 麻黄湯合葛根湯

すでに合方されている方鼡があるため, 構成処方 が重複する。これは温清飲と黄連解毒湯の合す， 柴苓湯と五苓散の合方，このような例が絶対ない とはいえませんが，非常に少ないと思います。こ らいった点は，上く知ってからやる場合もありま すが，一般的には黄連解毒湯之温清飲の合方は行 われないのが漢方の常識だと思います。同じょう にこれも当然そらであります。

同じ系統に属するもの，同じ作用を日指すもの の合方, これは大柴胡晹と柴胡桂枝乾类湯との命 方，あるいは八味地黄丸之六味丸との合力，腎虚 に対する処方を両方用いるといら点，これも何か の都合で 2 分の 1,3 分の 1 使らといらことはあ るかも知机ませんが，一般的にはどちらかで，间 じ系統に属するもの，同じ作用を目指すものの合 方というは, やはりまずいものであります。同 じょうに，桂枝获苓丸と桃核承気湯との合方も， 一般的には行わ机ない合方だと瑟います。

それから，誧があまりにもかけ離れているもの の組及合わせ。桃核承氛湯に真武湯の合方。これ も陰陽虚実が交錯，錯雑した場合には，こうした 例もあるいはあるか子知れませんが，一般的なも
のではないと思います。それから，含有生薬の重 複により, 副作用が出現する可能性がある場合。 これは麻黄湯および葛根湯の合方であります。こ の上らな例も，ときには 1 日分や 2 日分といら単 位で，行われるといらこともないわけではありま せんが，一般諭としてはないといらのは当然で， 代田先生のこのようなご注意には，敬服する次第 であります。

合方の原則といいますか,やってはいけないと いら意味での原則で，本当の原則というのは模索 段階であろらと思います。柴胡剂, 参耆剂, 人参 剂, 補気片, 麻黄剂, 瘀血剂, 温清飲の基本剂, 補腎剂など，たとえば柴胡剂であれば，大柴胡湯 と小柴胡湯の合方，このよらなものは满量合方は 行われないといらのが常識だろらと思います。こ れも半分半分であれば, 可能性が絶対ないとは中 しません。あるいは, 柴胡剂, 参者剂, 人参剤, 補気剂の各群間相百の 2 剂満量は, 原則としてあ まり行われない。たとえば，小柴胡湯と補中监気 湯の 2 剂満量といらのは, あまりよいとは思いま せん。どちらかにすべきだと思いますが，どうし ても使いたいといら場合は半々にするとか，ある いは 3 分の 2 にするとか, そらいら場合で行われ る壊合はあろらと思います。

\section{合方例のいろいろ}

合方例にはどらいらものがあるのかといらこと を，扣目にかけたいと思います。五苓散，小柴胡 湯, 葛根湯などを中心として, 拈目にか訂たいと 思います。諸先生方の合方例をまとめたものであ ります（表14〜17）。

五苓散を中心とした合方例としては，五苓散合 安中散で, 悪心, 嘔吐, 急性・慢性胃炎, 急性: 慢性の腸炎, 羿腸神経症, 悪阻, 腎炎などが, 五 苓散と安中散であります。血気刺痛して胃の病気 あるいはいろいろな婦人科疾患などでも, 五苓散 と安中散を合方する例は結構あろうと思います。

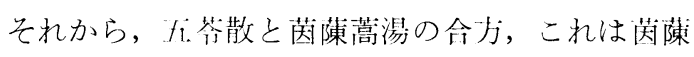
五苓散に通じるわけで，現在では茵萰五苓散があ るので，そのほらが多く用いられると思います が，五苓散と茵蔯蒿湯を合方するような場合もあ 
表14 五苓散を中心とする合方例

1. 安中散 (悪心・嘔吖, 急性 - 慢性胃炎, 急性 慢性腸炎, 胃腸神経症, 悪阻, 腎炎など)

2. 茵蔯蒿湯（茵蔯五苓散の意。肝炎，肝硬変，ネ フローゼ症候群，腎炎，胆囊炎，胆石症，急性・ 慢性胃炎，藻麻㷌など）

3. 黄連湯（急性・慢性胃炎，急性・慢性腸炎. 感 冒，二日酔い，アトピー皮膚炎など）

4. 九味檳榔湯 (浮腫, 腎炎, 急性・慢性胃炎, 心 蔵神経症，バセドウ病，脚気様症候群など）

5. 柴胡桂枝乾姜湯（感冒，腎炎，ネフローゼ症候 群, 肝炎, 急性・慢性胃炎, 急性・慢性腸炎, 過 敏性腸症候群など)

6. 柴胡桂枝湯 (感冒, 筲炎, ネフローゼ症候群, 急性・慢性胃炎, 急性・慢性腸炎, 過敏性腸症候 群など)

7. 小建中湯（悪心・嘔吐，急性・慢性胃炎，急 性・慢性腸炎, 胃腸神経症, 悪阻, 腎炎など)

8. 小柴胡湯（柴苓湯の意。腎炎，ネフローセ症候 群, 浮腫, 急性・慢性胃炎, 急性・慢性腸炎, 過 敏性腸症候群など)

9. 大建中湯（腹痛，急性・慢性胃炎，急性・慢性 腸炎，過敏性腸症候群，便秘など）

10. 大柴胡湯（腎炎，ネフローゼ症候群，浮腫，急 性・慢性胃炎，急性・慢性腸炎など）

11. 人参湯（急性・慢性胃炎, 急性・慢性腸炎, 渦 敏性腸症候群，便秘，下痢，嘔吖など）

12. 半夏瀉心湯（急性・慢性胃炎, 急性 - 慢性腸炎, 過敏性腸症候群，便秘，下痢，嘔吐など）

13. 苓桂术甘湯（急性・慢性胃炎, 急性 - 慢性腸炎, めまい,メニェール病，仮性近視など）

ろらと思います。肝炎，肝硬変，ネフローゼ，腎 炎，胆囊炎などによく用いられると思います。そ れから, 五苓散と黄連湯, これも急性・慢性胃 炎，急性・慢性腸炎，感冒，二日酔いなどにもよ く用いられると思います。黄連湯単味でも結構で すが，胃疾患は水毒を合併することが多いので， 五苓散との併用といらのは，薬が穏やかに効く結 果になると思いますので，五苓散を中心とする合 方として，黄連湯は大変意味があろうと思いま す。

五苓散と九味檳榔湯，五苓散と柴胡桂枝乾姜 湯，五苓散と柴胡桂枝湯の合方があります。

さらに五苓散と小建中湯, 五苓散と小柴胡湯,
表15 葛根湯を中心とする合方例

1. 黄連解毒湯（葛芩連湯の意。急性腎炎，急性腸 炎，口内炎，副鼻腔炎，結膜炎，皮膚疾患など）

2. 桔梗石膏 (感冒, インフルェンザ，咽喉部の痛 み，耳下腺炎など）

3. 桔梗湯（葛根湯加桔梗の意。感冒，インフルェ ンザ，咽喉部の痛み，耳下腺炎など）

4. 桂枝加术附湯（葛根加尤附湯の意。肩凝り，変 形性頸椎症，頸肩腕症候群，むちうち症など）

5. 四物湯（更年期障害，頸肩腕症候群，筋肉痛， 神経痛など)

6. 十味敗毒湯（扁桃炎，副鼻腔炎，中耳炎，皮䖉 疾患など）

7. 小柴胡湯（感冒，インフルェンザ，気管支炎， 扁桃炎，副鼻腔炎，中耳炎など）

8. 小柴胡湯加桔梗石高（柴葛解肌湯の意。感冒, インフルエンザ，気管支炎，扁桃炎，副鼻腔炎， 中耳炎など）

9. 小半夏加获苓湯 (葛根加半夏湯の意。慢性副鼻 腔炎，悪阻，感冒など）

10. 排膿散及湯（副鼻腔炎，中耳炎，麦粒腫，皮膚 化膿症など)

11. 白虎加人参湯（麻疹，高熱，上気道炎など）

表16加味逍遥散を中心とする合方例

1. 香蘇散（更年期障害，慢性胃炎，自律神経失調 症, 神経症など)

2. 酸栾仁湯（更年期障害，神経症，不眠など）

3. 四君子湯（慢性胃炎, 慢性腸炎, 過敏性腸症候 群，消化性潰瘍，皮䖉疾患など）

4. 四物湯（薄麻疹，皮膚疾患，更年期障害など）

5. 当帰四逆加呉莱莫生姜湯（更年期障害, 月経不 順，月経困難症，腹痛，腰痛，坐骨神経痛など）

6. 半夏厚朴湯（神経痛，心気症，更年期障害など）

7. ヨクイニン（尌麻疹，皮膚疾患，更年期障害な ぞ)

8. 苓桂术甘湯（自律神経失調症，低血圧症，慢性 胃炎, めまい, メニエール病など）

これは柴苓湯になるわけです。五苓散と大建中 湯。五苓散と大柴胡湯，これは腎炎，ネフローゼ 症候群，浮腫，急性・慢性胃炎，急性・慢性腸炎 など多くのものに用いられることになると思いま 于.

さらに，五苓散と人参湯，これは私は好きでよ く五苓散と人参湯を合方致します。あるいは五苓 
表17 小柴胡湯を中心とする合方剂

1. 安中散（急性・慢性胃炎, 急性 - 慢性腸炎, 胃 腸神経症, 過敏性腸症候群, 消化性 潰瘍, 胆囊 炎，胆石症，慢性肝炎，虚弱児の体質改善など）

2. 茵蔯蒿湯 (肝炎, 肝硬変, 胆囊炎, 胆石症, 急 性・慢性腎炎, 急性・慢性腸炎, 胃腸神経症, 腎 炎，ネフローゼ症候群，㻑麻疹など）

3. 茵蔯五苓散 (肝炎, 肝硬変, 胆囊炎, 胆石症, 急性・慢性胃炎, 急性・慢性腸炎, 胃腸神経症, 腎炎，ネフローゼ症候群，德麻疹など）

4. 温清飲 (慢性肝炎, 肝硬変, 口内炎, 神経症, 更年期障害，ベーチェット病，皮膚疾患など）

5. 越婢加术湯（感冒, インフルェンザ, 皮膚疾 患, 喘息その他アレルギー疾患など）

6. 黄連解毒湯 (高血圧, 肝炎, 腎炎, 神経症, ア レルギー疾患, 口内炎など)

7. 葛根湯（感冒，インフルェンザ，気管支炎，扁 桃炎，副鼻腔炎，中耳炎など）

8. 葛根湯加川节辛夷（扁桃炎，副鼻腔炎，中耳炎 など)

9. 葛根湯・桔梗石膏（柴葛解肌湯の意。感冒, イ ンフルェンザ, 咽頭炎, 喉頭炎, 気管支炎, 喘息 など）

10. 桔梗石膏 (扁桃炎, 咽頭炎, 感冒, インフルェ ンザ，気管支炎，喘息など）

11. 枯梗湯 (扁桃炎, 咽頭炎, 咽喉炎, 感冒, イン フルェンザ)

12. 桂枝加药薬湯 (てんかん, 急性 - 慢性腸炎, 過 敏性腸症候群，便秘など）

桂枝湯（感冒，インフルェンザ，気管支炎，喘 息など）

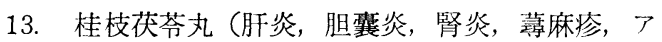
レルギー疾患, 膠原病など）

14. 桂麻各半湯（湿瘆, 皮膚炎, アトピー性皮膚炎 など)
15. 香蘇散(柴蘇飲の意。急性耳管炎, 出性中耳 炎，感冒，その他の慢性呼吸器疾患など）

16. 五虎湯 (感冒，インフルェンザ，気管支炎，喘 息など)

17. 五苓散 (柴苓湯の意。腎炎, ネフローゼ症候群, 浮腫, 急性・慢性胃炎, 急性・慢性腸炎, 過敏性 腸症候群など)

18. 柴胡清肝湯（出性中耳炎, 扁炎, 副鼻腔炎な 亡゙)

19. 四物湯（柴胡四物湯の意。肝炎，胆穰炎，腎炎 など)

20. 小建中湯（柴胡桂枝湯加莳薬の意。急性・慢性 胃炎, 急性 - 慢性腸炎, 胃腸神経症, 虚弱児の体 質改善など)

23. 猪苓湯（腎炎, 尿道炎, 膀胱炎, 前立腺炎, 尿 路結石など)

24. 当㷌药薬散（柴药湯の意。急性・慢性胃炎, 急 性・慢性腸炎, 腎炎, 神経症など)

25. 女神散（月経不順，月経困難症，更年期障害， 頭痛，神経症，不眠など）

26. 麦門冬湯（感冒，インフルェンザ，気管支炎， 喘息など)

27. 八味地黄丸（糖尿病, 腎炎, 腰痛, 神経痛, 慢 性泌尿器疾患など）

28. 半夏厚朴湯（柴朴湯の意。感冒，気管支炎，喘 息，神経症，慢性腎炎，虚弱児の体質改善など）

29. 白虎加人参湯・枯梗石膏 (感冒, インフルェン ザ，その他の急性感染症など）

30. 防已黄老湯 (腰痛, 神経痛, 変形性関節症, 変 形性瓷椎症，慢性関節リウマチ，腎炎など）

31. 麻杏甘石湯 (喘息, 気管支炎, 上気道炎など)

32. 竜胆瀉肝湯 (肝炎, 胆囊炎, 胆石症, 䐌炎, 慢 性泌尿器疾患など)

33. 苓桂术甘湯 (起立性調節障害, 自律神 経失調 症, メニエール病, めまい, 動悸, 頻脈など）
散と半夏瀉心湯，これも私は大变好きで，急性・ 慢性胃炎, 急性・慢性腸炎, 過敏性腸症候群, 便 秘，下痢，嘔吐など，こらいうものによく用いる と思います。あるいは五苓散と苓桂尤甘湯, 両方 とも水毒に対する処方ではないかと, あるいは获 苓，术が両方にあるのでまずいのではないかと拉 叱りを受けるかもわかりませんが，両方使わなけ ればならないといらケースもあろらかと思いま す。もちろん量の面への配慮が必要だろらと思い
ます。

葛根湯を中心とする合方例ですが，黄連解毒湯 との葛根黄芩黄連湯の意で, このような合方も考 えてみれば実はあったといらことであります。葛 根湯に桔梗石膏，これも私はよく使って拈りま す。葛根湯に桔梗湯，これは葛根湯加桔梗になる わけであります。葛根湯に桂枝加尤附湯を加光る と，葛根加尤附湯になるといらことです。いまは 葛根加术附湯の製剂もありますので，これを用い 
ればよいのですが，いざ葛根加术附湯を作りたい と思う場合には，このような合方もあるというこ とを思い出すと, 大変よいと思います。さらに, 葛根湯に四物湯の合方もあります。

それから, 葛根湯に十味敗毒湯, 蓦根湯に小柴 胡湯, あるいは葛根湯に小柴胡湯加枯梗石膏, こ れは柴葛解肌湯に近くなりますが，三陽の合病と しての柴葛解肌湯といら面で, 大变有用だろうと 思います。私は, 暮根湯に小柴胡湯というのは, 大変よく用いて扣ります。実際患者さんを毎日み ればよいのですが，かぜでどらしても 4 〜日， 1週間というように長引いてしまうという場合に は, 葛根湯に小柴胡湯を加えるといらのも, 大变 優れた応用法ではないかと思います。あるいは, 葛根湯に排膿敢及湯で, 副鼻腔炎, 中耳炎など, あるいは葛根湯に白虎加人参湯, このような合す 例もあるといらことを，後で私も気が付きました が，実際に使ってやったことはありませんが，非 常に招もしろい合方がございます。

加味逍遥散を中心とすると, 加味逍遥散に香蘇 散, あるいは酸霜仁湯, 四君子湯, 四物湯を合方 する。加味逍遥散に四物湯というのは, 私は大変 好きで, よく皮䖉疾患, とくに手掌角化症や主婦 湿疹, 更年期障害の場合に, 私は大変よく使いま す。山田先生は，これを合方されているようです が，私も以前から大変よく合方して打りました。 ところが，山田先生がこういらことをやっておら れるといらのを後で伺って，大变びっくりしたの であります。

それで，このような合方をやるのは，諸先生方 の扣吨りを受けるかと思って，私は実は隠れてや っていたのですが，期せずしていろんな先生方が やっておられることを目の当たりにして，大変感 激したものであります。

さらに加味逍遥散を中心とすると, 当帰四近加 吳莱莫生姜湯との合厅，これは私は大変好きで， とくに腰痛, 坐骨神経痛など, 多く試みておりま す。あるいは半夏厚朴湯, 萻莰仁, 苓桂术甘湯で あります。苓桂术甘湯との合方も，必要ないとい われる方もあるかと琶いますが，やはり水毒が強 くてめまいが大変強いといら方には, これらをや
ってはじめてよくなる場合もあります。

小柴胡湯を中心とする合方ですと, 安中散との 合方, あるいは小柴胡湯と茵蔯蒿湯, これは肝炎 を中心とした諸疾患で，大変多く用いられている と思います。あるいは肝硬変, 胆潩炎, 胆石症で あります。このように使ってきますと，非常に臨 床の幅が増えて, しかも多くの病態に対応するこ ともできると思います。

あるいは，小柴胡湯と茵蔯五苓散との合方，あ るいは温清飲との合方。これもべーチェット病や 口内炎, あるいは皮膚疾患で, 温清飲だけ使って いるとどうしてもよくならないときに，このよう な合方を試みると，意外によい場合もあると思い ます。あるいは, 小柴胡湯と越婢加术湯との合 方。私はときどき, アレルギー疾患, 花粉症, 喘 息などによく試みておりますが，このような合方 もございます。

あるいは小柴胡湯と黄連解毒湯との合方, ある いは小柴胡湯と葛根湯との合方, 小柴胡湯と葛根 湯加川芦辛夷との合方, これも扁桃炎, 副睤腔炎 がどらしても治りにくいという場侖，このような ことをやってみると, 大変よい場合がございま す。やはり病態が遷延性の場合に, 試みるべき合 方だろらと考えております。

さらに，小柴胡湯を中心とする合方例では，枯 梗石毫, あるいは小柴胡湯と枯梗湯, 小柴胡湯と 桂枝加芺薬湯，これはよく頡㾞に用いられます し，なくなった相見先生の創方といわれておりま すが，これによって柴胡桂枝湯加药薬が作られる わけであります。あるいは，急性・慢性の晹炎， 過敏性腸症候群，便秘などにもよいと思います。 小柴胡湯と桂枝湯，これを合方すれば柴胡桂枝湯 に近くなるわけですが，このよらな合方もありま す。

しかし，このような合方の場合，これがイコー ル柴胡桂枝湯というだけではなく，小柴胡湯を 5 $\mathrm{g}$ ，桂枝湯を $7.5 \mathrm{~g}$ といらように量の加減をする と，さらに細かい診療もできるのではないかと考 えております。実際に聯珠飲という処方をよく使 いますが，苓桂术甘湯の量を多くしてみたり，四 物湯の量を少なくしてみたり，いろんなパターン 
をやって，それなりの臨床との対比をしてみる と, いろいろな経験を得られて, 臨床上大变有用 な面が多いと考光ております。

さらには，小柴胡湯と桂枝获苓丸，これは肝炎 には常識的な処方といってもよいかも知れませ ん。よく用いられる処方ですが，もちろん肝炎の 場合は, 小柴胡湯に茵蔯蒿湯, あるいは茵蔯五苓 散との合方も大変よいと思います。あるいは，小 柴胡湯と桂麻各半湯, 湿疹や皮覤炎の非常に遷延 性の場合には，桂麻各半湯だけでなかなからまく いかない場合には, 小柴胡湯との合方も考えるべ きものだろうと思います。小柴胡湯に香蘇散を加 えて柴蘇散になるわけですが，これは耳下腺炎， 最近多い渗出性中耳炎, 感冒, 慢性呼吸器疾患な ど，多くの応用面があろうと思います。あるい は, 小柴胡湯之五虎湯, これも私は大変よく使う 処方ですが，インフルェンザ，気管支炎，喘息な ぞで遷延性の場合に，大変よいと思います。小柴 胡湯と五苓散との合方であれば，柴苓湯に通じま す。これは腎炎，ネフローゼ症候群，浮腫，急 性・慢性胃炎など, 多くの疾患に用いられると思 います。

小柴胡湯と柴胡清朋湯, これは私はよく渗出性 中耳炎に用いて打ります。扁桃炎, 副鼻腔炎な ぞ。最近は, 滲出性中耳炎が大変多く, 柴苓湯が 大変有用だといらご報告もあろらかと思います。 しかし，私は小柴胡湯に柴胡清肝湯という処方を よく使いまして，それなりに効いているよらに感 じています。柴胡清肝湯だけでは，食欲がない， かぜをひきやすいという点を補いにくいので，小 柴胡湯を加えると，そのような全身症状によりよ く対応できると考光て拈ります。

あるいは，小柴胡湯と四物湯との合方，これは 柴胡四物湯の意で, むかしから婦人科疾患や肺

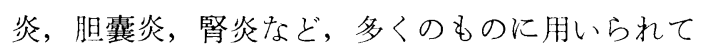
いるわけであります。あるいは，小柴胡湯と小建 中湯との合方, これは柴胡桂枝湯加莯薬, さらに 膠飴ですが，これに近くなろらかと思います。小 柴胡湯と小建中湯の合方は, 胃腸も弱い, さらに 呼吸器も弱いといら虚弱児の体質改善など, この ような処方が合う場合も大変多いと思います。昨
日, 中川先生からこのよらな処方を沶示し頂きま したが，これらの合方は，虚弱児の体質改善な ぞ, 多くの臨床的な適応領域を持っていると思い ます。

あるいは, 小柴胡湯と小青竜湯, これも感冒, インフルエンザで遷延した場合には，多くの適応 領域を持っていると思います。あるいは，小柴胡 湯と辛夷清肺湯。辛夷清肺湯は, 慢性副鼻腔炎に よく用いる処方ですが，さらに遷延して副鼻腔気 管支炎などを起こした場合には，私は小柴胡湯と の合方も必要だと思います。

小柴胡湯之猪苓湯との合方, これは慢性腎炎, 慢性疗道炎, 慢性前立腺炎など, 多くの合方を私 自身も行って扣ります。小柴胡湯に当帰苻薬散, 柴䒘湯ともいわれますが，これも腎炎や神経症， 急性・慢性胃炎, あるいは婦人科疾患など，多く のものに用いられる可能性があると思います。あ るいは, 小柴胡湯と女神散, これも多くの適応領 域を持っていると思います。私自身は，これを使 った経験はございません。小柴胡湯と麦門冬湯, これは私は大変よく愛用する処方で, 感冒, イン フルェンザ，気管支炎，喘息など，さらに私はこ のような場合, 麻杏甘石湯なり五虎湯を, 汪んの $2 \sim 3 \mathrm{~g}$ 加えるといらこともやっておりますが， そうするとさらによく気管支炎，喘息などの咳に 対応しやすい場合もございます。漢方は証によっ て用いるわけですから，いろいろな症状観察の 上，腹証，脈証をみた上で使うのが原則であるこ とはもちろんであります。

さらに小柴胡湯と八味地黄丸, これもよく用い る合方だと思います。糖尿病, 腎炎, 腰痛症, 神 経痛, 慢性泌尿器疾患など。あるいは小柴胡湯と 半夏厚朴湯, これは柴朴湯になるわけですが，多 くの適応領域を持っていることは周知のことと思 います。あるいは，小柴胡晹と白虎加人参湯に枯 梗石膏のの合力゙・加方はかなり高熱が出たよらな 場合ですが，最近はあまりないと思いますが麻㡎 であるとか，感冒で高熱が壮たよらな場合，この よらな合力が用いられる可能性があると思いま す。そういう場合に，ぜひやってみたい合方だと 思います。 
表18 日本医薬品集の解説

[適 応]

承認された効果（ただし，承認を要しない医薬品は 医学薬学上認められた範囲内), 長期間投薬適用除 外期限, 保険診療上必要な情報も載せている。

例 3 桂枝获苓丸の場合

（漢方処方では，基準として，いわゆる 210 処方で取り上げられたものの効能又は効果 を記載し，これ以外の適応を持つものは別 に記載している)

[適応]基準 : 比較的体力があり，ときに下腹部 痛，肩こり，頭重，めまい，の洼せて足冷觉な ぞを訴える次の諸症：月経不順，月経異常，月 経痛，更年期障害，血の道症，肩こり，めま い, 頭重，打ち身 (打撲症)，しもやけ，乙み

ツムラ：体格はしっかりしていて赤ら顔が多 く, 腹部は大体充尖, 下腹部に抵抗のあるもの の次の諸症: 子宮内膜炎, 月経不順, 月経困難, 帯下，更年期障害（頭痛，めまい，のぼせ，肩 こり等), 冷え症, 腹膜炎, 打撲傷, 痔疾患, 睪丸炎

現在の医療用漢方製剂はここで言う「規準」（一般 用漢方 210 処方の規準) に準じて大多数の製剤が涩 可されている。

さらに，小柴胡湯と防已黄耆湯との合方，ある いは麻杏甘石湯との合方，これは私が大変よく行 ら合方で，小柴胡湯と麻杏甘石湯は，ほとんど毎 日のように使っております。小柴胡湯と竜胆瀉肝 湯, これは慢性肝炎, 慢性胆囊炎などにも, 試み てょい処方だろらと思います。それから，慢性泌 尿器疾患で，どらしても竜胆瀉肝湯だけでは対応 しにくい場合, やはり小柴胡湯の必要性があるよ らな場合には, 慢性泌尿器疾患で慢性前立腺炎な ど多くの疾患があると思いますが，これらのもの にも試みてよい処方だと思います。あるいは，小 柴胡湯と苓桂术甘湯との合方, 起立性調節障害, メニエールなど，めまい，動悸，頻脈などにも， 合方できる可能性のある処方だと思います。

\section{漢方方剤の適応症とその問題点}

漢方と保険問題との，若干の関連に触れてみた いと思います。表18は『日本医薬品集』の解説で すが，桂枝获苓丸について，ここに書いてありま
表19 小柴胡湯の適応症

A）体力中等度で上腹部がはって苦しく，舌苔を生 じ，口中不快，食欲不振，時により微熱，覀心な ぞのあるものの次の諸症：諸種の急性熱性病，肺 炎, 気管支炎, 感冒, 胸膜炎・肺結核などの結核 性諸疾患の補助療法, リンパ腺炎, 慢性胃腸障害, 肝機能障害, 産後回復不全

B）吖き気, 食欲不振, 胃炎, 胃腸虚弱, 疲労感及 び風邪の後期の症状

C) (1)微熱があって頭痛, 頭重, 疲労倦怠感を自覚 するもの，また熱感や微熱がとれず，あるいは熱 と悪寒が交互に現れ，咳を伴うものの次の諸症： 感冒，気管支炎，気管支喘息，麻疹。(2)胸や脇腹 に圧迫感を自覚し悪心や嘔吐，腹痛なぞを伴い舌 に白苔があって, 胃部が重苦しく食欲が減退する ものの次の諸症：腎臓疾患, 胃腸病, 悪阻。(3)腺 病体質で疲れ易く抵抗力が乏しく, 体力の回復が ながびくものの次の症状：腺病質の体質改善

D）胸や脇腹が重苦しく，疲れやすくて微熱があっ たり熱感と悪感が交互にあったりして，食欲少な く，時に舌苔があり，悪心，嘔吐，咳嗽を伴うな ぞの症状があるもの：感冒，気管支炎，気管支喘 息, 胁膜炎, 胃腸病, 胸部疾患, 肝蔵病などの消 耗性疾患の体力增強, 腎臓病, 貧血性, 腺病質

す。

「承認された効果…桂枝获苓丸 …現在の医療用漢 方製剤は，ここでいら基準，一般用漢方 210 処方 の基準に準じて，大多数の製剤が認可されていま †」

これが現実だと思います。現在の医療用の漢方 製剂は，一般用漢方 210 処方の基準に準じて，も ちろん準じたわ壮ですから，それに付け加わった ようないろんな症状もありますが，あくまでもそ れに準じて大多数の製剤が認可されているといら ことを，認識すべきだと私は思います。

この 210 処方の処方と申しますと，実は昭和 44 年, 厚生省薬務局, その当時製薬課といって㧊り ましたが，現在の新医薬品課，審査課の合わさっ たものですが，その前身の製薬課に，漢方打ち合 わせ会といらものができ，大塚敬節先生，他 3 名， 2 人の医系之 2 人の薬系の先生が委員でした。奏 は医系のもら1人に私が入っていたのです。この 4 人の委員が，一般用漢方製剤の処方，配合生薬 
表20 小柴胡湯の適応症の比較

\begin{tabular}{|c|c|c|c|}
\hline $\mathrm{A}$ & B & $\mathrm{C}$ & $\mathrm{D}$ \\
\hline $\begin{array}{l}\text { 諸種の急性熱性病, 肺炎, } \\
\text { 気管支炎, 感冒, 胸膜炎· } \\
\text { 肺結核などの結核性諸疾 } \\
\text { 患の補助療法, リンパ腺 } \\
\text { 炎, 慢性胃腸障害, 肝機 } \\
\text { 能障害, 産後回復不全 }\end{array}$ & $\begin{array}{l}\text { 吐き気, 食欲不振, 胃炎, } \\
\text { 胃腸虚弱, 疲労感及び風 } \\
\text { 邪の後期の症状 }\end{array}$ & $\begin{array}{l}\text { (1) 感冒, 気管支炎, 気 } \\
\text { 管支喘息, 麻疹 } \\
\text { (2) 腎臓疾患, 胃腸病, } \\
\text { 悪阻 } \\
\text { (3) 腺病質の体質改善 }\end{array}$ & $\begin{array}{l}\text { 感冒, 気管支炎, 気管 } \\
\text { 支喘息, 肋膜炎, 胃腸 } \\
\text { 病, 胸部疾患, 肝臓病 } \\
\text { などの消耗性疾患の体 } \\
\text { 力増強, 腎臓病, 貧血 } \\
\text { 性, 腺病質 }\end{array}$ \\
\hline
\end{tabular}

の用量, 効能または効果を審議致しました。主と してこれは, 昭和の漢方医学成書を元にして, 上 記を作成したわけであります。

小柴胡湯の適応症としては, 現在 4 種類ござい ます(表19)。ある会社のものでは体力中等度で云 々という, 肝機能障害, 産後回復不全までであり ます。

ある会社のものでは，一般用のものと全く同じ で，一般用のかぜの後期の症状といら適応症が書 いてあります。慢性肝炎や風邪以外の呼吸器疾患 などは何も書いてありません。

ある会社のものでは, 微熱があって, あるいは 胸や脇腹に圧迫感を自覚しというように, やや漢 方的に表現された効能もございます。

またもう一つ別のは, 胸, 脇腹が重苦しく, 疲 れやすく, 微熱があったり, 熱感と悪寒が交互に あったりして，食欲が少なく，ときに舌苔があ り, 悪心, 嘔吐, 咳嗽などを伴う諸症のあるもの として，このような疾患をあげております。 小柴胡湯に関しては，以上 4 種類あるわけです が, その適応症をみると,いろいろな差があります (表20)。肝機能障害といら言葉は A 社分の効能が あるだけで，泳かに $\mathrm{D}$ 社に肝藏病の体力増強があ ります。 $\mathrm{B}, \mathrm{C}$ 社の効能には肝疾患はありません。 漢方製剂の健康保険審査基準の問題 点という と, まず第一に各メーカーによって認可の適応性 の問題, それから漢方医学的見地, あるいは最近 の臨床的報告, やはり私はこのようなものを参考 にすべきだと思います。私の信念といってよいか も知れませんが, 漢方はやはり漢方医学的見地か ら審査を行われるべきだと考えて打ります。
メーカーの適応症は, シバリと病名の二つがあ ります。

漢方医学的見地による審查というのは, 病名か ら推定可能な場合と, 明細書に症状あるいは証の 併記が必要な場合と二つあるわけです。しかし， どらいら場合にどちらがよいのかといらことは， 審査委員の見方によって違ってくると思います。

漢方医学的見地というのは，210 処方の処方が 用いられた段階では, 大塚先生, 矢数先生, 山田 先生の各著書, 大塚先生と矢数先生々清水先生の 共著合計 4 書がその当時は標準となっていまし た。これを元にして，210 処方の内容が作られた わけで, やはり漢方処方の内容的には, 生薬構成 と分量は遵守されるべきだと思います。もちろん 病態によって量が増えるのは結構だと思います。 さらに, 日本医師会の医薬品カードもその後出て 打りますし，本学会での漢方保険診療指針という ものも出て沏ります。

最近の研究や報告に基づく審査, これは滲出性 中耳炎には柴苓湯, 不妊症に莳薬甘草湯, 脳動脈 硬化症に黄連解毒湯, シェーグレン病に麦門冬湯 といったようなものに使うということも，保険診 療報酬の明細書にコメントしても有用ではないか と私は考光て招ります。

以上漢方製剂の 2 剂合方の運用について, 諸先 生方の経験を集めた文献を元にして若干解説し, 保険診療の問題点なども指摘しました。これらの ことにより，先生方が明日の䛦療に执いてよりよ く患者さんに対応でき，さらに漢方診療において 多くの先生方にプラスになれば，これに過ぎる喜 びはありません。ご静聴ありがとうございました。 